ORIGINAL ARTICLE

\title{
Knowledge, Practice and Attitude of Hepatitis B Infection and its Prevention among Nurses in a Tertiary Eye Care Center of
} Delhi

\author{
Suman R Kashyap ${ }^{1}$, Seema Sachdeva ${ }^{2}$, Yangchen Dolma ${ }^{3}$, Anita Sarin ${ }^{4}$, Shakti K Gupta ${ }^{5}$
}

\begin{abstract}
Background: Hepatitis B infection is a common disease all over the world. According to its endemicity, countries are divided into three groups (high, intermediate, low). India falls in the intermediate endemicity zone (prevalence of 2-8\% with an average of $4 \%$ ). The risk of contracting hepatitis B virus (HBV) is four times greater for healthcare workers, compared to that of the general adult population. So, the study was aimed to assess knowledge, practice, and attitude of nursing officers regarding hepatitis B infection and its prevention, its association with selected variables, and correlation between knowledge and practice.

Materials and methods: A cross-sectional survey was carried out among 180 nursing officers working in an ophthalmic center of a tertiary care hospital using 38 items, self-administered questionnaire with three sections for knowledge, practice, and attitude regarding HBV infection and its prevention. The data were collected in the morning and evening shift as per the subject's availability after obtaining a written consent from subjects. The analysis was performed using the statistical analysis software.

Results: Among 180 respondents, $8 \%$ had poor knowledge whereas $92 \%$ showed adequate knowledge about HBV infection and its prevention. Poor knowledge was apparent in items like diet required in hepatitis infection (29\%); otherwise, in rest all the areas, adequate knowledge was observed. Regarding practice, $14 \%$ had poor practices whereas $86 \%$ showed good practices. With regard to attitude, majority of the subjects had positive attitude for the items like risk of getting HBV infection (80\%), importance of HBV vaccination (97\%), and using universal precaution (98\%). Uncertainty and disagreement showing negative attitude was observed in items like revealing the HBsAg+ve status at work (73\%), sharing utilities with an infected person (71\%), feeling stressed to take care of an infected patient (38\%), fear of social isolation ( $80 \%)$, and vaccination for an HBV-infected patient (60\%).
\end{abstract}

Keywords: Hepatitis B virus, Infection prevention, Vaccination.

International Journal of Research Foundation of Hospital and Healthcare Administration (2019): 10.5005/jp-journals-10035-1104

\section{INTRODUCTION}

Hepatitis B infection is one of the major public health problems and leading causes of morbidity and mortality worldwide. ${ }^{1}$ In India, the prevalence of hepatitis B infection among the general population ranges from 2 to $8 \%$, which puts India at the second place in the global pool for hepatitis B infection. ${ }^{2}$ India has point prevalence of $2.1 \%$ and carrier rate of $1.7 \%$ for hepatitis B virus (HBV) infection. Some studies have shown higher carrier rate ranging from $11 \%$ in healthcare workers to $5 \%$ in general population. ${ }^{3}$ Hepatitis $B$ is an important occupational hazard for healthcare workers due to transmission via blood and body fluids. With the increasing number of invasive diagnostic and therapeutic procedures, the risk of infection among healthcare workers is two to four times greater than that of general adult population. About 66,000 hepatitis $B$ viral infections are reported per year due to needle-stick injuries. Hence, the adherence to universal precautions is critical to prevent HBV transmission. ${ }^{4}$ Along with this, a complete vaccination status is important for workers in the healthcare setting to reduce the risk of vaccine-preventable diseases (VPDs) among both healthcare workers and patients. Enhancing the knowledge about hepatitis $B$ and crafting prevention practices are the major strategies to the prevention of the disease to a great extent. Knowledge and practices of healthcare workers play a key role in prevention of spread of infection. ${ }^{5}$ Therefore, the present study aimed to assess the knowledge of risk factors for hepatitis B infection, its vaccination, and frequency of vaccination among the nursing officers in tertiary
${ }^{1,3-5} \mathrm{Dr}$ Rajendra Prasad Centre for Ophthalmic Sciences, All India Institute of Medical Sciences, New Delhi, India

${ }^{2}$ College of Nursing, All India Institute of Medical Sciences, New Delhi, India

Corresponding Author: Shakti K Gupta, Dr Rajendra Prasad Centre for Ophthalmic Sciences, All India Institute of Medical Sciences, New Delhi, India, Phone: +919818837782, e-mail: shakti810505@gmail. com

How to cite this article: Kashyap SR, Sachdeva $S$, Dolma $Y$, et al. Knowledge, Practice and Attitude of Hepatitis B Infection and its Prevention among Nurses in a Tertiary Eye Care Center of Delhi. Int $J$ Res Foundation Hosp Healthc Adm 2019;7(1):19-23.

Source of support: Nil

Conflict of interest: None

eye care hospital, New Delhi, India. The objectives were to assess knowledge, practice, and attitude of nursing staff regarding hepatitis B infection and its prevention, its association with selected variables, and correlation between knowledge and practice.

\section{Objective}

To assess knowledge, practice, and attitude of nursing officers regarding hepatitis $B$ infection and its prevention, its association with selected variables, and correlation between knowledge and practice. 


\section{Materials and Methods}

A cross-sectional survey was carried out among nursing personnel working in the ophthalmic center of a tertiary care hospital, New Delhi, from April 2018 to July 2018. The total enumeration sampling method was used for a total population of 236. The subjects who were not available at the time of study or who did not gave consent were excluded. Finally, the 180 subjects participated in the study in filling questionnaire. A 38-items, self-administered questionnaire with 3 sections for knowledge, practice, and attitude was used along with 14 items related to sociodemographic characteristics and the self-reported vaccination status. The tool was validated by experts for face, content, and criteria validity. The internal consistency of the tool was calculated by appropriate statistical formulas. After getting ethical permission from the institute ethical committee (Protocol no. IEC/76/2/2018), a written informed consent from respondents was obtained. Subjects were assured about the confidentiality of their responses and their right to withdraw from the survey at any time. The data were collected in the morning and evening shift as per the subject's availability. Data were entered in the master sheet analyzed using the statistical analysis software (SAS). Descriptive statistics were used to illustrate demographic characteristics. Categorical variables were measured as percentages, while continuous variables were expressed as mean \pm standard deviation. Inferential statistics (ANOVA, $t$ test, $p<0.05$ ) were used to assess the significance among study variables. Pearson coefficient correlation $(p<0.05)$ was used to evaluate the association between knowledge and practice.

\section{Results}

Of the 236 participants, 180 (90\%) completed the survey. The findings of 180 subjects showed that the majority of subjects (47\%) were in the age group of 30-40 years, females were the dominant gender (89\%), and 98 (54\%) had diploma in nursing and 64\% subjects had 2-5 years of professional experience. Majority (50\%) were working in ophthalmic wards and OPDs. Around $83 \%$ subjects had never attended any in-service education related to hepatitis $B$. Most of the subjects were nonsmokers and nonalcoholic. Surprisingly, $60 \%$ subjects were never tested for hepatitis $B$, and $62 \%$ indicated that they had not received a vaccine for HBV.

\section{Assessment of Knowledge}

Table 1 describes the knowledge of subjects regarding HBV infection and its prevention for each item under yes or no response. Knowledge score ranged from 18 (maximum) to 0 (minimum). The mean knowledge score for the entire study cohort was $15.29 \pm 2.46$. A cutoff level of $<11$ was considered as poor whereas $\geq 11$ was considered as adequate knowledge about HBV. Among 180 respondents, 14 (8\%) had poor knowledge whereas 166 (92\%) showed adequate knowledge about HBV infection and its prevention.

Poor knowledge was apparent in items like diet required in hepatitis infection (29\%) and vaccination schedule (53\%). Whereas good knowledge was observed in items like availability of vaccine $(96 \%)$, screening in prenatal (89\%), and transmission of infection (94\%) (Table 1).

\section{Assessment of Practices toward Hep B Infection and Prevention}

Practice was assessed by asking eight questions with yes or no response as shown in Table 2 . The total scores ranged from 8 (maximum) to 0 (minimum). The mean practice score was $6.60 \pm 1.14$.

\begin{tabular}{|c|c|c|c|}
\hline S. no. & Knowledge items & $\begin{array}{l}\text { Correct } \\
\text { responsesf }(\%)\end{array}$ & $\begin{array}{l}\text { Incorrect } \\
\text { responses F (\%) }\end{array}$ \\
\hline 1 & $\begin{array}{l}\text { Is hepatitis B a bacterial } \\
\text { disease? }\end{array}$ & $135(75)$ & $45(25)$ \\
\hline 2 & $\begin{array}{l}\text { Can hepatitis B cause } \\
\text { liver cancer? }\end{array}$ & $110(61)$ & $70(39)$ \\
\hline 3 & $\begin{array}{l}\text { Can hepatitis B affect } \\
\text { any age group? }\end{array}$ & $173(96)$ & $7(4)$ \\
\hline 4 & $\begin{array}{l}\text { Is jaundice a common } \\
\text { symptom of hepatitis B? }\end{array}$ & $155(86)$ & $25(14)$ \\
\hline 5 & $\begin{array}{l}\text { Can hepatitis B spread } \\
\text { through mother to child } \\
\text { in pregnancy? }\end{array}$ & $151(84)$ & $29(16)$ \\
\hline 6 & $\begin{array}{l}\text { Can hepatitis } B \text { be } \\
\text { transmitted by unsafe } \\
\text { sex? }\end{array}$ & $130(72)$ & $50(28)$ \\
\hline 7 & $\begin{array}{l}\text { Transmission of hepatitis } \\
\text { B by sterilized syringes/ } \\
\text { needles }\end{array}$ & $130(72)$ & $50(28)$ \\
\hline 8 & $\begin{array}{l}\text { Can hepatitis B be } \\
\text { transmitted by used } \\
\text { blades for shaving } \\
\text { purpose? }\end{array}$ & $156(87)$ & $24(13)$ \\
\hline 9 & $\begin{array}{l}\text { Is hepatitis B transmitted } \\
\text { by contaminated water } \\
\text { and food? }\end{array}$ & $118(65)$ & $62(35)$ \\
\hline 10 & $\begin{array}{l}\text { Treatability of hepatitis } \\
\text { B with present line of } \\
\text { treatment }\end{array}$ & $134(74)$ & $46(26)$ \\
\hline 11 & $\begin{array}{l}\text { Availability of } \\
\text { vaccination for } \\
\text { protection from } \\
\text { hepatitis B }\end{array}$ & $173(96)$ & $7(4)$ \\
\hline 12 & $\begin{array}{l}\text { Specific diet required for } \\
\text { Нер B }\end{array}$ & $53(29)$ & $127(71)$ \\
\hline 13 & $\begin{array}{l}\text { Are nausea, vomiting, } \\
\text { and loss of appetite } \\
\text { common symptoms of } \\
\text { hepatitis B? }\end{array}$ & $154(85)$ & $26(15)$ \\
\hline 14 & $\begin{array}{l}\text { Common symptoms of } \\
\text { acute hepatitis B }\end{array}$ & $145(80)$ & $35(20)$ \\
\hline 15 & $\begin{array}{l}\text { Can hepatitis B spread } \\
\text { through unscreened } \\
\text { blood or blood } \\
\text { products? }\end{array}$ & 169 (94) & $11(6)$ \\
\hline 16 & $\begin{array}{l}\text { Screening of hepatitis } B \\
\text { required in the prenatal } \\
\text { period }\end{array}$ & $161(89)$ & $19(11)$ \\
\hline 17 & $\begin{array}{l}\text { The schedule of Hep B } \\
\text { vaccination }\end{array}$ & $96(53)$ & $84(47)$ \\
\hline 18 & $\begin{array}{l}\text { Therapy after exposure } \\
\text { to Hep B infection }\end{array}$ & $102(57)$ & $78(43)$ \\
\hline
\end{tabular}

A cutoff level of $<5$ was considered as poor practice whereas $\geq 5$ was considered as good practice for Hep B infection prevention. Out of 180 subjects, 26 (14\%) had poor practices with scores $<5$ whereas $154(86 \%)$ showed good practices with scores $>5$.

Poor practices were observed for sharing items with an $\mathrm{HBV}+\mathrm{ve}$ person (35\%). Whereas good practices were observed in items like 
Table 2: Response of the subjects regarding Hep B infection-prevention practices $(n=180)$

\begin{tabular}{llcc}
\hline S.no. & Practice items & Yesf $(\%)$ & No F (\%) \\
\hline 1 & $\begin{array}{l}\text { Do you take a new sterile syringe } \\
\text { before use? }\end{array}$ & $177(98)$ & $3(2)$ \\
2 & $\begin{array}{l}\text { Do you look for screening of blood or } \\
\text { blood products before transfusion? }\end{array}$ & $175(97)$ & $5(3)$ \\
3 & $\begin{array}{l}\text { Do you ask for change of blade before } \\
\text { any procedure like shaving by barber } \\
\text { or ear piercing? }\end{array}$ & $170(94)$ & $10(6)$ \\
4 & $\begin{array}{l}\text { Do you recap the needle after use? } \\
\text { Do you cut the needles and syringe }\end{array}$ & $173(24)$ & $137(76)$ \\
6 & $\begin{array}{l}\text { hub before final disposal? } \\
\text { Do you share your items (food/ } \\
\text { utensils/water) with an HB+ve per- }\end{array}$ & $62(35)$ & $118(65)$ \\
7 & $\begin{array}{l}\text { son? } \\
\text { Do you wear PPE (personal protective } \\
\text { equipment) while dealing with blood } \\
\text { and blood products? }\end{array}$ & $172(95)$ & $8(5)$ \\
8 & $\begin{array}{l}\text { Have you completed your hepatitis B } \\
\text { vaccination? }\end{array}$ & $115(64)$ & $65(36)$ \\
\hline
\end{tabular}

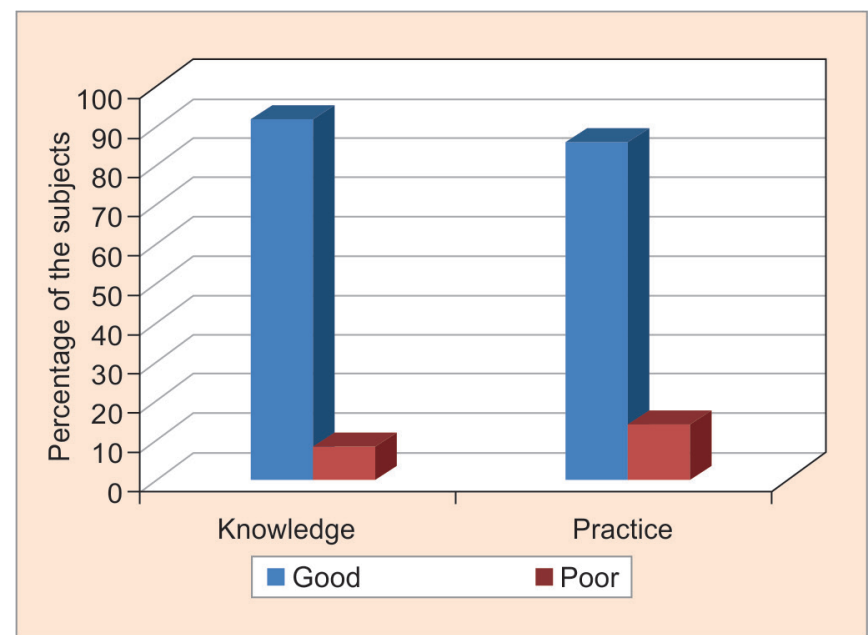

Fig. 1: Knowledge and practices of the subjects regarding hepatitis $B$ infection and prevention

using sterile syringes, screening of blood, and use of fresh blades before shaving (94-98\%) (Table 2).

The comparison of knowledge and practices in Figure 1 shows that majority of the subjects had both good knowledge and practices regarding hepatitis $B$ infection and prevention.

\section{Assessment of Attitude}

Attitude toward hepatitis B and its prevention was assessed by 10 items. Each question was ranked under agree, disagree, and uncertain categories. The respondents were allowed to choose to only one response as shown in Table 3. Ranking was performed under positive and negative attitude.

Majority of the subjects had positive attitude for the items like risk of getting $\mathrm{HBV}$ infection (88\%), importance of HBV vaccination (97\%), and using universal precaution (98\%). Uncertainty and disagreement showing negative attitude was observed in items like revealing the $\mathrm{HBsAg}+\mathrm{ve}$ status at work (53\%), sharing utilities of a positive person with a noninfected person (58\%), feeling stressed
Table 3: Attitude item and its responses $(n=180)$

\begin{tabular}{|c|c|c|c|c|}
\hline S. no. & $\begin{array}{l}\text { Items related to } \\
\text { attitude }\end{array}$ & Agree f (\%) & $\begin{array}{l}\text { Disagreef } \\
\text { (\%) }\end{array}$ & $\begin{array}{l}\text { Uncertain } \\
f(\%)\end{array}$ \\
\hline 1 & $\begin{array}{l}\text { Are you at risk to get } \\
\text { hepatitis B? }\end{array}$ & $158(88)$ & $7(4)$ & $15(8)$ \\
\hline 2 & $\begin{array}{l}\text { Would you feel } \\
\text { stress to take care of } \\
\text { such patient? }\end{array}$ & 71 (39) & $73(41)$ & $36(20)$ \\
\hline 3 & $\begin{array}{l}\text { Do you feel hepatitis } \\
\text { B vaccination is } \\
\text { important? }\end{array}$ & $175(97)$ & $2(1)$ & $3(2)$ \\
\hline 4 & $\begin{array}{l}\text { Would you like } \\
\text { to reveal your HB } \\
\text { status at work, if } \\
\text { present? }\end{array}$ & $83(46)$ & $15(8)$ & $82(45)$ \\
\hline 5 & $\begin{array}{l}\text { Would you feel fear } \\
\text { of social isolation/ } \\
\text { stigmatized with HB } \\
\text { infection? }\end{array}$ & $63(35)$ & $72(40)$ & $45(25)$ \\
\hline 6 & $\begin{array}{l}\text { Should a hepatitis B } \\
\text { patient allowed to } \\
\text { work routinely? }\end{array}$ & $127(70)$ & $30(17)$ & $23(13)$ \\
\hline 7 & $\begin{array}{l}\text { Should an HB } \\
\text { patient be allowed } \\
\text { to perform } \\
\text { strenuous exercises? }\end{array}$ & $40(22)$ & $92(51)$ & $48(27)$ \\
\hline 8 & $\begin{array}{l}\text { Should an HBV- } \\
\text { infected patient/ } \\
\text { staff be allowed to } \\
\text { share his utilities? }\end{array}$ & $60(33)$ & $104(58)$ & $16(9)$ \\
\hline 9 & $\begin{array}{l}\text { The patient with } \\
\text { HB infection should } \\
\text { get hepatitis B } \\
\text { vaccination }\end{array}$ & 107 (59) & $46(26)$ & $27(15)$ \\
\hline 10 & $\begin{array}{l}\text { Do you take extra } \\
\text { precautions for a } \\
\text { known case of an } \\
\text { HbsAg+ve patient? }\end{array}$ & $176(98)$ & $3(2)$ & 1 \\
\hline
\end{tabular}

to take care of an infected patient (61\%), and vaccination for an HBV-infected patient (59\%).

\section{Correlation between Knowledge and Practice}

To find the correlation of knowledge with practice, a Pearson coefficient correlation was used with $95 \%$ level of significance $(p=0.05)$. Significant positive linear correlations were observed between knowledge and practice with $r=0.42$ and $p=0.001$.

\section{Association of demographics characteristics with mean knowledge, practice, and attitude scores}

Table 4 describes the association of demographic characteristics like age, gender, education, experience, in-service education, and positive case of hepatitis B infection.

The variables like age, education, and experience were found to be statistically significant with $p<0.05$ with knowledge and practice of subjects regarding hepatitis infection and its prevention. The knowledge and practices were better in younger age group (20-30 years) than $30-40$ years ( $p=0.002$ for knowledge and $p=0.009$ for practice) and $>40$ years ( $p=0.005$ for knowledge and $p=0.001$ for practice). In education, degree holder subjects had more knowledge and good practices than diploma holders with $p=$ 0.008 and $p=0.001$, respectively. Similarly, both knowledge and 
Knowledge, Practice and Attitude of Hepatitis B Infection and Its Prevention

Table 4: Association of demographic characteristics with mean knowledge and practice scores

\begin{tabular}{|c|c|c|c|c|c|}
\hline Variables & $N$ & Mean Kmean $\pm S D$ & $p$ value & Mean p mean $\pm S D$ & $p$ value \\
\hline \multicolumn{6}{|c|}{ Age (in years) ${ }^{\#}$} \\
\hline $20-30$ & 33 & $16.12 \pm 1.89$ & $0.001^{*}$ & $7.36 \pm 0.78$ & $0.01^{*}$ \\
\hline $30-40$ & 84 & $15.68 \pm 2.3$ & & $6.63 \pm 1.01$ & \\
\hline$>40$ & 63 & $15 \pm 2.23$ & & $6.10 \pm 1.37$ & \\
\hline \multicolumn{6}{|l|}{ Gender@ } \\
\hline Male & 19 & $16.05 \pm 2.19$ & 0.32 & $6.68 \pm 1.05$ & 0.69 \\
\hline Female & 161 & $15.20 \pm 2.48$ & & $6.59 \pm 1.15$ & \\
\hline \multicolumn{6}{|c|}{ Education@ } \\
\hline GNM & 98 & $14.73 \pm 0.26$ & $0.008^{*}$ & $6.26 \pm 0.12$ & $0.001^{*}$ \\
\hline Bsc Nsg & 82 & $15.9 \pm 0.23$ & & $7 \pm 0.09$ & \\
\hline \multicolumn{6}{|c|}{ Experience (in years) ${ }^{\#}$} \\
\hline$<2$ & 19 & $15.5 \pm 1.9$ & $0.05^{*}$ & $6.98 \pm 0.89$ & $0.001^{*}$ \\
\hline $2-5$ & 116 & $16.6 \pm 1.52$ & & $7.15 \pm 0.84$ & \\
\hline$>5$ years & 45 & $14.5 \pm 2.50$ & & $6.42 \pm 1.16$ & \\
\hline \multicolumn{6}{|c|}{ In service education@ } \\
\hline Yes & 45 & $15.54 \pm 2.52$ & 0.89 & $6.68 \pm 1.30$ & 0.71 \\
\hline No & 135 & $15.21 \pm 2.45$ & & $6.58 \pm 1.05$ & \\
\hline
\end{tabular}

"ANOVA, ${ }^{\circledR}$ two sample $t$ test, ${ }^{*} p<0.05$ significant

practices were better in subjects with $2-5$ years of experience than less experienced $(<2$ years; $p=0.52$ for knowledge and $p=0.05$ for practice) and also more experienced subjects $(>2-5$ years; $p=0.001$ for knowledge and $p=0.01$ for practice).

\section{Discussion}

The prevalence rate of hepatitis B viral infection is about 2-10 times higher among healthcare workers than the general populations mainly due to percutaneous or mucosal exposure to infected blood or body fluids, using inadequately sterilized medical or surgical equipment or contact with the nonintact skin. ${ }^{6,7}$ Despite increasing prevalence of this viral infection and increased risk among healthcare workers, there is paucity of information on knowledge and safe practices especially in developing countries like India. ${ }^{8}$ The present study conducted in tertiary care center, New Delhi, India, revealed that majority of the subjects had overall adequate knowledge (166 out of 180) and fair practices (154 out of 180) regarding hepatitis B infection and its prevention. Around three-fourth of the respondents in this study correctly mentioned the route of transmission of HBV, which was similar to other studies conducted among dental, nursing, and medical students in India. 9,10 However, answer to some items like diet showed inadequate knowledge. Similarly, poor attitude was found in sharing items with an HBV-infected person. A similar study on healthcare workers in Ghana showed overall knowledge and practices as satisfactory but lack of knowledge on fatality of the disease, other types of viral hepatitis, the route of transmission, and poor practices for recapping needle and needle-stick injury prevention. ${ }^{10}$ Another similar study in Nigeria (2015) suggested most of the respondents underestimate the risk of transmission and this may put healthcare workers at risk of being infected with these pathogens following exposure. ${ }^{11}$ The present study also identified good compliance with the use of simple personal protective equipment such as gowns, caps, and mask and goggles. The evidences of the present study revealed the need for consistent and appropriate safety precautions by hospital personnel as only $64 \%$ subjects were fully vaccinated for hepatitis B. The findings are consistent with a study done in a tertiary care hospital, Delhi, India (2009), which reported that only $55.4 \%$ healthcare workers were vaccinated against hepatitis $B$, though there was adequate knowledge and fair practices. ${ }^{12}$ With regard to attitude, majority of the subjects had a positive attitude for the risk of getting $\mathrm{HB}$ infection, importance of $\mathrm{HB}$ vaccination, and using universal precaution. Whereas a negative attitude was observed for sharing utilities with infected person, feeling stressed to take care of a seropositive patient, and revealing self seropositive status for HB at work and fear of social isolation. The findings go in line with the study done in southern Nigeria that displayed negative attitudes of healthcare workers regarding knowing their HBV status and patient's screening. ${ }^{13}$ The demographics like age, education, and experience showed a significant association with knowledge and practice of subjects. The findings go in line with the study in Northwest Ethiopia on infection-control practices among healthcare workers, which suggested that older age, lengthy work experience, and a higher educational status were significantly associated with both knowledge and practice of infection prevention. ${ }^{14} \mathrm{~A}$ positive but weak correlation was found between knowledge score and practice $(r=0.42, p=0.001)$. The finding of weak correlation between good knowledge and good practice suggests that knowledge does not always translate into good practice. Whereas a positive correlation for awareness level and attitude was found in a study done on healthcare workers. ${ }^{5}$

\section{Limitations}

The study was conducted in single center of a tertiary care hospital. The findings could vary among subjects from one center to other. The information was gathered via self-administered questionnaires, so the actual practices may vary from the responses given. The vaccination status was assessed through self-provided information, which is prone to recall bias.

\section{Conclusion}

The overall knowledge and practice was adequate among subjects. Good knowledge and practices were observed for specific items 
like use of personal protective equipment and recap and cutting of needle before disposal. Subjects had negative attitude for revealing seropositive status for $\mathrm{HbsAg}$ and sharing utilities with an infected person. Compliance of healthcare workers to hepatitis $B$ vaccination deserves serious attention.

\section{Recommendations}

Regular training and handholding activities are required to be an essential part of in-service education. The Indian Health Ministry should make hepatitis $B$ vaccination mandatory for all healthcare professionals. Antibody titers should be routinely checked among those who are vaccinated.

\section{References}

1. Vinodhkumaradithyaa A, Srinivasan M, Sankarasubramanian RA, et al. Hepatitis B vaccination among medical students. Indian J Community Med 2008;33:67-68. DOI: 10.4103/0970-0218.39254.

2. Singhal V, Bora D, Singh S. Hepatitis B in health care workers: Indian scenario. J Lab Physicians 2019;1:41-48. DOI: 10.4103/0974-2727.59697.

3. Choudhury P, Mishra S, Kandula S, et al. Awareness of hepatitis B infection among healthcare students in a private medical college in Odisha. J Int Soc Prevent Communit Dent 2015;5(S2):63-67. DOI: 10.4103/2231-0762.171260.

4. World Health Organization Guidelines for the prevention, care and treatment of persons with chronic Hepatitis-B infection. Geneva: WHO Library Cataloguing-in-Publication Data, 2015, (ISBN 978924 154905 9).

5. Gunson RN, Shouval D, Roggendorf M, et al. Hepatitis B virus (HBV) and hepatitis $\mathrm{C}$ virus (HCV) infections in health care workers (HCWs): guidelines for prevention of transmission of HBV and HCV from HCW to patients. J Clin Virol 2003;27:213-230. DOI: 10.1016/S13866532(03)00087-8.

6. Patil S, Rao RS, Agarwal A. Awareness and risk perception of hepatitis B infection among auxiliary healthcare workers. J Int Soc Prev Community Dent 2013;3:67-71. DOI: 10.4103/2231-0762.122434.

7. Singh A, Jain S. Prevention of hepatitis B; knowledge and practices among medical students. Healthline 2011;2:8-11.

8. Batham A, Narula D, Toteja T, et al. Systematic review and metaanalysis of prevalence of hepatitis B in India. Indian Pediatr 2007;44:663-674.

9. Sivarajasingam V, Laszlo J, Ogden GR. Extent of hepatitis $B$ immunization among dental and medical students. Br Med J 1995;311:231. DOI: 10.1136/bmj.311.6999.231.

10. Yasobant. A study to assess knowledge and awareness about the hepatitis $B$ and $C$ among nursing college students of central India. J family med community health 2017;4(8):1136, from: https://www. researchgate.net/publication/282424489.

11. Kesieme EB, Uwakwe K, Irekpita E, et al. Knowledge of Hepatitis $B$ vaccine among operating room personnel in Nigeria and their vaccination status. Hepat Res Treat 2011;2011:157089. DOI: 10.1155/2011/157089.

12. Singhal V, Bora D, Singh S. Hepatitis B in health care workers: Indian scenario. J Lab Physicians 2009;1(2):41-48. DOI: 10.4103/09742727.5969710.4103/0974-2727.59697.

13. Samuel SO, Aderibigbe SA, Salami T, et al. Health workers' knowledge, attitude and behaviour towards hepatitis B infection in Southern Nigeria. Int J Med Sci 2009;1:418-424.

14. Desta M, Ayenew T, Sitotaw N, et al. Knowledge, practice and associated factors of infection prevention among healthcare workers in Debre Markos referral hospital, Northwest Ethiopia. BMC Health Services Research 2018;18:465. DOI: 10.1186/s12913-018-3277-5. 